\title{
S sciendo \\ FACTORS OF SUCCESSION OF POLISH FAMILY PRODUCTION AND MIXED ENTERPRISES
}

doi:10.2478/mape-2018-0071

Date of submission of the article to the Editor: 05/2018

Date of acceptance of the article by the Editor: 07/2018

MAPE 2018, volume 1, issue 1, pp. 561-567

\section{PhD. Mariola Dźwigoł-Barosz}

Silesian University of Technology, Poland

\section{Prof. Dmytro Lazarenko, PhD.}

Donbas State Pedagogical University, Ukraine

\begin{abstract}
The article presents issues in the area of succession of family enterprises. Particular attention has been paid to succession processes in Polish enterprises, with particular emphasis on the upcoming generational change of family entrepreneurs.

The factors determining a successful succession process in family enterprises were indicated on the basis of the research cited in the authors' study and the methodology for examining the factors determining the succession process of Silesian family enterprises was presented. The results of the own research questionnaire in the form of a ranking of factors according to the successors and nestors of the examined production and mixed enterprises were presented.
\end{abstract}

Keywords: succession, family businesses

\section{INTRODUCTION}

The market economy is based largely on family businesses, which makes the problem of succession is current and important (Bracci and Vagnoni, 2011). Experience shows that $50 \%$ of family enterprises will cope with problems related to succession and only $15 \%$ will manage to transfer the company to the third generation (Sułkowski and Mariański, 2009).

The uniqueness of family enterprises can be seen in their predominance resulting from a longterm vision, the ability to make quick decisions and apply an approach based on trust, loyalty and personal relationships. Awareness of the fact that many companies in Poland face key decisions related to the transfer of knowledge, power and property is increasing. The first wave of succession is coming, during which companies are to be handed over by the founders who took the risk, put their work, energy and assets into creating a business. The first generational change is connected with the need for the senior and his family to define a new vision of the company, as well as to establish new systems of values and formal regulations in the field of ownership and power in the family business.

The aim of the study is to pay special attention to the importance of the succession process of Polish family enterprises, with particular emphasis on the factors determining the success of this process.

\section{SUCCESSION IN POLISH FAMILY ENTERPRISES}

In October 2015 during the 5th European Congress of SMEs in Katowice: On family businesses, J. Klimek ${ }^{1}$ pointed out that the greatest problem in family businesses is succession.

\footnotetext{
${ }^{1}$ Dr hab. Jan Klimek - deputy president of the Polish Craft Association, director of the Institute of Entrepreneurship at the Warsaw School of Economics, president of the Chamber of Crafts and Small and Medium Enterprises in Katowice and a member of the European Economic and Social Committee.
} 
Most Polish family businesses were established in the 1990s, for the next 20 years they increased their capital, structures and developed trade relations in new markets (Surdej and Wach, 2010).

At present, the founders are most often already around the age of 50 and face the challenge of handing over the successor's business management. According to studies by Sułkowski, conducted in the years 2004-2005, the majority of family enterprises in Poland (85\%) are directed by the founders, only every tenth enterprise is run by the next generation. As many as $72.5 \%$ of the surveyed entities are to be transferred to successors. The vast majority of CEOs as successors indicate children, while not being able to take any legal steps in this regard (Sułkowski and Mariański, 2009).

As per the Family Business Survey report (Mirkowski, 2014) only $12 \%$ of family businesses are able to survive up to the third generation, and only $1 \%$ of companies can boast of a history of activity for more than five generations.

Among the most frequently cited reasons affecting the short lifespan of family businesses are listed (Lewandowska et al., 2012):

- poor planning of inheritance and resulting inability to pay by the next generation of inheritance tax,

- not giving the company to the younger generation at the right moment, the inability to choose a successor (many families have more than one child, which raises,

- the question of how to solve the issue of inheritance and to which the descendant pass the management of the enterprise).

The cause of the fall of the family business may also be the lack of interest in a potential successor of a family business, or the conflict between siblings and the lack of agreement on the takeover of the company (Lewandowska et al., 2012).

Unfortunately, many Polish entrepreneurs still do not have a plan of succession, understood as a gradual transfer of power to the young generation and its introduction into the company's structures. Although the awareness of this topic is growing, in practice, however, only a small percentage of companies have a plan of succession.

According to the results of the research of the report "Family companies in the face of change" carried out by PwC and the Institute of Family Business (Raport, 2016), the plan of succession exists only in $9 \%$ of companies. This lack is important, as $72 \%$ of respondents from Poland declared that they want to transfer the management of the company to representatives of the younger generation.

Increasingly, however, owners of family enterprises recognize the necessity of the process of transferring the company into the hands of the next generation, being aware of the fact that improper performance may cause the company to fall. From the Institute of Family Business.

\section{FACTORS DETERMINING A SUCCESSFUL SUCCESSION PROCESS IN FAMILY ENTERPRISES}

It should be remembered that the change process requires many years of preparation. Owners of family enterprises often do not realize the complexity of the succession process, they also distract the whole process in time to avoid problems and conflicts that may be associated with this.

As confirmed by the report on the Value Codes project (Lewandowska, 2015), families are often too late to start talking about the future of the company and rarely take up the topic of succession.

In family enterprises, succession should be a comprehensive, long-term and strictly planned process in which, in addition to formal requirements and competences, family values, rules of conduct and traditions of an enterprise should also be taken into account.

Many researchers and practitioners in the family business environment are of the opinion that the responsibility for ensuring succession lies mainly with the founders and owners of these companies (Danco, 1975). 
The harmoniousness of the succession depends on the coexistence of two conditions: firstly, the willingness of the company to resign (in the case of companies managed by owners and founders there may be emotional identification with the company and delay or lack of consent to leave) and availability and obviousness (unequivocal) in the choice successor (Pramodita et al., 2009).

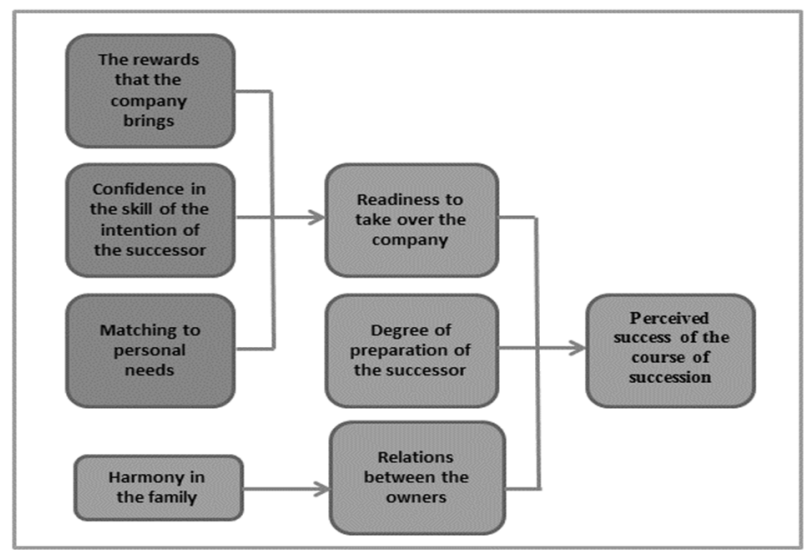

Fig. 1. Factors affecting the successful course of succession

Source: (Venter et al., 2005).

Figure 1 presents the factors affecting the successful course of succession. The authors draw attention to the fact that the rewards that lead a family business is not only financial benefits but also satisfaction and self-fulfillment. The key role is also played by trust in the potential successor, his life interests and harmony in the family, which is shaped over many years through open communication, mutual respect and readiness to recognize mutual achievements.

In practice, there are several ways to introduce descendants to a family enterprise. For some companies, children are gradually implemented from the lowest positions in order to familiarize with the specificity of the activity and learn about various aspects of its functioning. In many cases, parents exert pressure on children related to the orientation of their education according to the profile of the company's activity, while others in turn give their descendants a free hand in the area of choosing the direction of education. Observing, however, the environment of family businesses, it is difficult to find a method that would guarantee the effectiveness of the chosen way of introducing successors.

The project of succession does not result from the need of the moment and is a process that must be carefully planned and properly executed. The implementation of the succession planning process is based, among others, on: (Olkiewicz, 2013)

- selecting the most important positions that are necessary for the proper functioning of the family business,

- analysis and assessment of threats and risks that result from handing over the company to the successor,

- formulation of important requirements needed to select a potential successor,

- selection of presumed successors and arranging a special program to develop their competences,

- overseeing the progress and motivation of potential successors.

Based on observations and more than twenty years of practice of managing a family business A. Blikle (Blikle, 2012) claims that the best way to prepare a successor is to see how the future successor goes through the next levels of the company's career. He points out that promotions should be based on knowledge and competences. If the employees come to the conclusion that the owner's child has an easier path of promotion compared to non-family workers, they will not respect the new owner. Some family entrepreneurs, in order to completely eliminate 
the danger of an easier career path, require future founders to set up and run their own business for some time. It is only when they check on this level that they are admitted to the board of a family business.

\section{METHODOLOGY OF RESEARCH ON FACTORS DETERMINING THE SUCCESSION PROCESS OF SILESIAN FAMILY AND MIXED FAMILY ENTERPRISES}

The research was carried out in the Silesian Voivodeship in the period from September 2016, until February 2017. 7 and 9 family enterprises that meet the following criteria took part in the first and second stage tests:

- a family enterprise is an economic entity in which: at least two family members work together in this enterprise; at least one member of the family has a significant influence on the management, the - family members have majority shares in the enterprise,

- the enterprise is considered to be family,

- intends to hand the company over to the next generation,

- is a limited liability company - a limited liability company or a joint stock company in accordance with the Code of Commercial Companies,

- exists on the market for at least 10 years,

- belongs to the group of small or medium enterprises,

- is a production or mixed enterprise (production and service),

- has its headquarters in Poland in the province of Silesia

Additional criteria for conducting the research process are as follows:

Stage I - the family enterprise is in the hands of at least the second generation (at least once the process of succession has passed).

Stage II has "successive potential", i.e. the owners have offspring (joint or partner), the family enterprise is before the succession process, the decision on the selection of the successor was initially or definitively made taken.

In the first stage of the research, questionnaire surveys with 7 successors after succession were carried out, managing family enterprises at least as a second generation.

In turn, in the second stage, questionnaire surveys were carried out with the senior citizens of 9 family enterprises before the succession process.

In the studies of stages I and II, 11 factors determining the succession process were evaluated for successors and seniors in order to assess them in terms of severity in the five-degree scale ( 1 - the lowest score, 5 - the highest) of each factor determining the succession process in a family enterprise. Respondents also had the opportunity to propose factors other than those mentioned that determine the succession process.

These factors include?:

- good relationships with parents,

- good relations between the successor and other family members,

- good relations between successor and employees,

- good relations with clients,

- trust in the successor,

- belief in the skills of the successor,

- the interest of the successor in the business,

- knowledge of the industry/market,

- experience in the industry,

- education,

- clear criteria for the division of property,

- other (what kind?)

At the outset, the analysis of the successor and nestor ratings was made, which is reflected in the content of table 1. It was assumed that if the inter-class distribution is no greater than 1 , the respondents agree in their opinions.

${ }^{2}$ Succession factors have been developed on the basis of literature research on the subject. 
Table 1

Compliance of successor and senioror ratings

\begin{tabular}{|c|c|c|c|c|}
\hline $\begin{array}{l}\text { FACTORS DETERMINING THE } \\
\text { SUCCESSION PROCESS }\end{array}$ & $\begin{array}{l}\text { U Manna- } \\
\text { Whitneya }\end{array}$ & $\mathbf{Z}$ & p-value & INTERPRETATION OF RESULTS \\
\hline good relationships with parents & 3.500 & -3.232 & .001 & $\begin{array}{l}\text { the answers of seniors and successors } \\
\text { are statistically different }\end{array}$ \\
\hline $\begin{array}{l}\text { good relations between the } \\
\text { successor and other family } \\
\text { members }\end{array}$ & 23.500 & -.927 & .354 & \\
\hline $\begin{array}{l}\text { good relations between successor } \\
\text { and employees }\end{array}$ & 10.500 & -2.366 & .018 & $\begin{array}{l}\text { the answers of seniors and successors } \\
\text { are statistically different }\end{array}$ \\
\hline good relations with clients & 18.500 & -1.485 & .138 & \\
\hline trust in the successor & 10.500 & -2.605 & .009 & $\begin{array}{l}\text { the answers of seniors and successors } \\
\text { are statistically different }\end{array}$ \\
\hline faith in the successor's skills & 28.500 & -.354 & .723 & \\
\hline $\begin{array}{l}\text { the interest of the successor in the } \\
\text { business }\end{array}$ & 21.000 & -1.248 & 212 & \\
\hline knowledge of the industry/market & 19.500 & -1.380 & .168 & \\
\hline experience in the industry & 24.500 & -.860 & .390 & \\
\hline education & 21.000 & -1.247 & .212 & \\
\hline $\begin{array}{l}\text { clear criteria for the division of } \\
\text { property }\end{array}$ & 6.000 & -2.874 & .004 & $\begin{array}{l}\text { the answers of seniors and successors } \\
\text { are statistically different }\end{array}$ \\
\hline
\end{tabular}

Comparing in pairs the significance of differences between means of individual factors, groups of factors were created for which these differences are statistically insignificant. In this way, a ranking of factors determining a good succession process for successors and nestors was obtained. The form of the ranking is presented in Table 2.

Table 2

Ranking of factors determining the succession process

\begin{tabular}{|c|c|c|c|c|c|}
\hline \multicolumn{3}{|c|}{ Ranking - successors } & \multicolumn{3}{|c|}{ Ranking - nestors } \\
\hline $\begin{array}{c}\text { Place in } \\
\text { the ran- } \\
\text { king }\end{array}$ & $\begin{array}{l}\text { Factors determining the } \\
\text { succession process }\end{array}$ & $\begin{array}{c}\text { Average } \\
\text { assessment } \\
\text { of the } \\
\text { successors }\end{array}$ & $\begin{array}{l}\text { Place } \\
\text { in the } \\
\text { ran- } \\
\text { king }\end{array}$ & $\begin{array}{l}\text { Factors determining the } \\
\text { succession process }\end{array}$ & $\begin{array}{c}\text { Average } \\
\text { assessment } \\
\text { of the } \\
\text { nestors }\end{array}$ \\
\hline \multirow[t]{2}{*}{1} & $\begin{array}{l}\text { good relationships with } \\
\text { parents }\end{array}$ & 5.00 & \multirow[t]{2}{*}{1} & education & 4.35 \\
\hline & trust in the successor & 5.00 & & trust in the successor & 4.22 \\
\hline \multirow[b]{2}{*}{2} & education & 4.35 & 2 & faith in the successor's skills & 4.07 \\
\hline & $\begin{array}{l}\text { faith in the successor's } \\
\text { skills }\end{array}$ & 4.07 & \multirow{3}{*}{3} & $\begin{array}{l}\text { good relations between the } \\
\text { successor and other family } \\
\text { members }\end{array}$ & 3.71 \\
\hline \multirow{4}{*}{3} & $\begin{array}{l}\text { good relations between the } \\
\text { successor and other family } \\
\text { members }\end{array}$ & 3.71 & & good relations with clients & 3.67 \\
\hline & good relations with clients & 3.67 & & $\begin{array}{l}\text { good relationships with } \\
\text { parents }\end{array}$ & 3.56 \\
\hline & $\begin{array}{l}\text { good relations between } \\
\text { successor and employees }\end{array}$ & 3.43 & \multirow{2}{*}{4} & $\begin{array}{l}\text { the interest of the successor } \\
\text { in the business }\end{array}$ & 3.21 \\
\hline & $\begin{array}{l}\text { clear criteria for the division } \\
\text { of property }\end{array}$ & 3.43 & & $\begin{array}{l}\text { knowledge of the } \\
\text { industry/market }\end{array}$ & 3.03 \\
\hline \multirow{2}{*}{4} & $\begin{array}{l}\text { the interest of the } \\
\text { successor in the business }\end{array}$ & 3.21 & \multirow{2}{*}{5} & $\begin{array}{l}\text { good relations between } \\
\text { successor and employees }\end{array}$ & 2.44 \\
\hline & $\begin{array}{l}\text { knowledge of the } \\
\text { industry/market }\end{array}$ & 3.03 & & experience in the industry & 2.33 \\
\hline
\end{tabular}


Analyzing the obtained research results, it can be noticed that the factor of the greatest importance in the process of succession, according to successors and nestors, is trust in the successor. As equally important successors, they recognized good relations with parents, who were assigned by third-in rank in the ranking. The factor of the highest importance according to the nestor - education, successors placed on the spot II. Belief in the successor's skills was recognized by both successors and nestors as an important factor determining the succession process (both groups assigned him the second place in the ranking). Respondents were also in agreement in the case of such factors as: good relations between the successor and other family members and good relations with clients. In both cases, these factors took the third place. Conformity assessment also applies to the fourth group of succession factors, where successors and nestors have placed the interest of the successor in business and knowledge of the industry/market. The factor considered by the senior households to be of the least importance in the examined process is quite surprising - clear criteria for the division of property. The successors qualified him in the third group of the ranking. In turn, the least importance for the successors is the experience in the industry, where the nestors likewise qualified him in the penultimate ranking group.

Both in the case of the group of successors and seniors, none of the respondents declared their willingness to identify other than the proposed factors in the process.

\section{CONCLUSION}

Family enterprises are the oldest way to run a business and are one of the foundations of the global economy. Their creation, functioning and collapse have a major impact both on the development of the national and global economy. The long-term perspective of running a business for future generations, as well as combining family and managerial functions, gives such entities a clear identification (Sułkowski and Marjański, 2009).

In many definitions of family enterprises the importance of the topic of succession is repeatedly emphasized as an inseparable element of such an entity. In turn, for family businesses, succession is a matter that determines their survival and development.

The subject of the succession of Polish family enterprises is not sufficiently researched due to the fact that the vast majority of such entities are enterprises in the hands of the first generation. Many companies have already stopped or will face the problem of transferring power, knowledge and property in the near future. The succession process is complex, multistage, requires many years of preparation and involvement of family members related to the company's operations.

It is necessary to pay special attention to the factors that determine the process of successful succession, because it is a complex process of developing and implementing a strategic plan of transferring ownership and power by the current owner (or owners) of the family company to a chosen successor who will be able to ensure continuity and development a family enterprise in accordance with the established strategy.

\section{REFERENCES}

Blikle, A. (2012). Specyfika zarządzania w firmach rodzinnych. In: Firma w rodzinie czy rodzina w firmie. Metodologia wsparcia firm rodzinnych. Warszawa: PARP, p. 43.

Bracci, E. and Vagnoni, E. (2011). Understanding Small Family Business Succession in Knowledge Management Perspective. The IUP Journal of Knowledge Management, p. 8.

Danco, L. (1975). Beyond survival - A business owner's guide for success. Cleveland: University Press. http://katowice.naszemiasto.pl/artykul/kongres-msp-w-katowicach-o-firmach-rodzinnychzdjecia,3538857,art gal,t,id,tm.html [Accessed 13 Nov. 2015].

Instytut Biznesu Rodzinnego,(2015). Badanie Firm Rodzinnych 2015 - Polska na tle Europy ŚrodkowoWschodniej i świata. [online] Available at: http://www.ibrpolska.pl/raporty/raport-testowy-2/ [Accessed 26 Feb. 2014]. 
Lewandowska, A., Greser, J. and Jakubowski, J. (2012). Sukcesja w firmie rodzinnej. In: Firma w rodzinie czy rodzina w firmie. Metodologia wsparcia firm rodzinnych. Warszawa: PARP, pp. 121-122.

Lewandowska, A. (2015). Kody wartości. Diagnoza sytuacji sukcesyjnej w przedsiębiorstwach rodzinnych w Polsce. Syntetyczny raport z badań przeprowadzonych w ramach projektu „Kody wartości - efektywna sukcesja w polskich firmach rodzinnych". [online] Available at: http://www.ibrpolska.pl/raporty/diagnoza-sytuacji-sukcesyjnej-w-przedsiebiorstwach-rodzinnychw-polsce/ [Accessed 13 Mar. 2015].

Mirkowski, S. (2014). Jak zbudować wielopokoleniowy biznes rodzinny? Głos Biznesu, 3(29), p. 28.

Olkiewicz, M. (2013). Jakość zasobów ludzkich determinantą procesu sukcesji. Przedsiębiorczość i Zarządzanie, Firmy rodzinne - wyzwania globalne i lokalne, t. XIV, z. 6, cz. 1, p. 67.

Pramodita, P., Chua, J.H. and Chrisman, J.J. (2009). Perceptions about the Extend of Succession Planning in Canadian Family Firms. Canadian Journal of Administrative Sciences, 17(3), pp. 233244.

Raport: Badanie firm rodzinnych. (2016). Firmy rodzinne w obliczu zmian. [online] Available at: https://www.pwc.pl/pl/pdf/firmy-rodzinne-raport-pwc-2016.pdf.

Sułkowski, Ł. and Marjański, A. (2009). Firmy rodzinne. Jak osiągnąć sukces w sztafecie pokoleń. Warszawa: Poltext, p. 9, 39, 46, 51.

Surdej, A. and Wach, K. (2010). Przedsiębiorstwo rodzinne wobec wyzwań sukcesji. Warszawa: Difin, p. 12.

Venter, E., Boshoff, C. and Maas, G. (2005). The Influence of Successor Related Factors on the Succession Process in Small and Medium Sized Family Business. Family Business Review, 18(4), pp. 283-303. 